P-ISSN 2580 - 7781

E-ISSN $2615-3238$

\title{
PENGARUH MOTIVASI KERJA, KOMPETENSI, DAN LINGKUNGAN KERJA TERHADAP KEPUSAN KERJA KARYAWAN PT. INDAH PLYWOOD BONDOWOSO
}

\section{EFFECT OF WORK MOTIVATION, COMPETENCY, AND WORK ENVIRONMENT ON EMPLOYEE JOB SATISFACTION OF PT. INDAH PLYWOOD BONDOWOSO}

\author{
Mohammad Yahya Arief ${ }^{1)}$, Muhammad Fauzi Ahmad ${ }^{2)}$ \\ ${ }^{1,2}$ Fakultas Ekonomi, Universitas Abdurachman Saleh Situbondo \\ ${ }^{1}$ Email: yarief104@gmail.com
}

\begin{abstract}
ABSTRAK
Tujuan penelitian ini yaitu untuk mengetahui pengaruh variabel motivasi, kompetensi, dan lingkungan kerja secara parsial terhadap variabel kepusan kerja karyawan, untuk mengetahui pengaruh variabel motivasi, kompetensi, dan lingkungan kerja berpengaruh secara simultan terhadap variabel kepusan kerja karyawan, untuk mengetahui variabel motivasi, kompetensi, dan lingkungan kerja yang paling dominan berpengaruh terhadap variabel kepusan kerja karyawan. Metode yang digunakan dalam penelitian ini adalah uji validitas, uji reliabilitas, Uji Asumsi Klasik, analisis regresi linier berganda, uji t, uji F dan uji determinasi. Hasil persamaan regresi linier berganda yaitu $\mathrm{Y}=-2,578 \mathrm{E}-17+$ $0,199 \mathrm{X} 1+0,337 \mathrm{X} 2+0,344 \mathrm{X} 3+e$. Uji t menunjukkan variabel motivasi kerja sebesar $\mathrm{t}_{\text {hitung }} 2,076>\mathrm{t}_{\text {tabel }} 1,989$ sig $0,041<0,05$, kompetensi sebesar $\mathrm{t}_{\text {hitung }} 3,451>\mathrm{t}_{\text {tabel }} 1,989 \mathrm{sig}$ $0,001<0,05$, lingkungan kerja sebesar $\mathrm{t}_{\text {hitung }} 3,578>\mathrm{t}_{\text {tabel }} 1,989$ sig $0,001<0,05$ artinya variabel variabel motivasi kerja, kompetensi dan lingkungan kerja berpengaruh secara parsial terhadap kepuasan kerja karyawan. Uji $\mathrm{F}$ menunjukkan nilai $\mathrm{F}_{\text {hitung }} 12,487>\mathrm{F}_{\text {tabel }}$ 2,72 sig 0,000 < 0,05 bahwa variabel motivasi kerja, kompetensi, lingkungan kerja berpengaruh secara simultan terhadap kepuasan kerja karyawan. Variabel lingkungan kerja berpengaruh dominan terhadap kepuasan kerja karyawan. $\mathrm{R}$ square sebesar sebesar $31,4 \%$ terhadap variabel terikat dan sisanya sebesar $68,6 \%$ dipengaruhi oleh variabel lain yang tidak diteliti.
\end{abstract}

Kata kunci : Motivasi, Kompetensi, Lingkungan kerja, Kepuasan kerja

\section{ABSTRACT}

The purpose of this study is to determine the effect of the motivation, competence, and work environment variables partially on the employee satisfaction variable, to determine the effect of the motivation, competence, and work environment variables simultaneously influence the employee job satisfaction variable, to determine the motivation, competence, and the work environment that most dominantly influences the employee job satisfaction variable. The method used in this research is validity test, reliability test, Classical Assumption Test, multiple linear regression analysis, $t$ test, $F$ test and determination test. The results of the multiple linear regression equation are $Y=$ $2,578 E-17+0,199 X 1+0,337 X 2+0,344 X 3+e$. The t-test shows the work motivation variable of $t_{\text {count }} 2,076>t_{\text {table }} 1,989$ sig $0,041<0,05$, competence of $t_{\text {count }} 3,451>t_{\text {table }}$ 1,989 sig 0,001 $<0,05$, work environment of $t_{\text {count }} 3,578>t_{\text {table }} 1,989$ sig $0,001<0,05$, this means that the variables of work motivation, competence and work environment have a partial effect on employee job satisfaction. F test shows the value of $F_{\text {count }} 12,487$ > $F_{\text {table }} 2,72$ sig 0,000 $<0,05$ that the variables of work motivation, competence, work environment have a simultaneous effect on employee job satisfaction. The work environment variable has a dominant effect on employee job satisfaction. $R$ square of 
P-ISSN 2580 - 7781

E-ISSN $2615-3238$

$31.4 \%$ of the dependent variable and the remaining $68.6 \%$ is influenced by other variables not examined.

Keywords: Motivation, Competence, Work environment, Job satisfaction

\section{PENDAHULUAN}

Manusia sebagai sumber daya manusia dalam pelaksanaan pembangunan memiliki peran penting karena manusia merupakan pelaksana dalam pembangunan. Suatu pembangunan dapat terlaksana dengan baik memerlukan kualitas sumber daya manusia (SDM) yang unggul dan berkualitas, maka diperlukan suatu proses SDM. Manajemen sumber daya manusia merupakan salah satu bidang dari manajemen umum yang meliputi segi-segi perencanaan, pengorganisasian, pelaksanaan, dan pengendalian. Proses ini terdapat dalam fungsi atau bidang kekaryawanan, karena sumber daya manusia dianggap sangat penting. Perannya dalam pencapaian tujuan perusahaan, maka berbagai pengalaman dan hasil penelitian dalam bidang SDM dikumpulkan secara sistematis dalam apa yang disebut manajemen sumber daya manusia.

Menurut Mangkunegara (2009:2) manajemen sumber daya manusia adalah suatu pengelolaan dan pendayagunaan sumber daya yang ada pada individu. Pengelolaan dan pendayagunaan tersebut dikembangkan secara maksimal di dalam dunia kerja untuk mencapai tujuan organisasi dan pengembangan individu karyawan. Unsur utama dalam kemajuan organisasi adalah SDM, sebagai motor penggerak, insipirasi dan juga sebagai otak berjalannya suatu organisasi, SDM memberikan pengaruh yang sangat besar. Semakin baik SDM yang dimiliki oleh organisasi maka akan semakin baik kinerja dari organisasi itu sendiri, sebaliknya, semakin rendah kualitas mutu SDM yang dimiliki oleh organisasi akan menjadi kinerja organisasi menurun dan pada akhirnya akan mengakibatkan organisasi hancur. Organisasi merupakan sebuah kumpulan dari beberapa orang yang memiliki tujuan yang sama dan untuk mewujudkan tujuan tersebut bersama-sama pula. Apabila suatu organisasi tidak terdapat unsur kepercayaan dari satu orang dengan beberapa orang atau kelompok, maka organisasi tersebut tidak akan terwujud. Oleh sebab itu, perlu dibentuk adanya kebiasaan atau tata tertib yang akan memberikan suatu budaya organisasi. 
Motivasi merupakan hal yang sangat penting untuk diperhatikan oleh pihak perusahaan bila menginginkan setiap karyawan dapat memberikan andil positif terhadap pencapaian tujuan perusahaan, karena dengan motivasi seorang karyawan akan memiliki semangat yang tinggi dalam melaksanakan tugas dan tanggung jawabnya. Pentingnya motivasi karena motivasi adalah hal yang menyebabkan, menyalurkan, dan mendukung perilaku manusia supaya mau bekerja giat dan antusias mencapai hasil yang optimal (Hasibuan, 2010:141). Menurut Sutrisno (2010:110), motivasi adalah faktor pendorong seseorang untuk melakukan suatu aktifitas tertentu, motivasi seringkali diartikan sebagai faktor pendorong perilaku manusia. Sedangkan motivasi kerja ialah faktor pendorong atau daya penggerak untuk bekerja bagi karyawan dalam sebuah perusahaan. Motivasi kerja dapat memacu karyawan untuk bekerja keras sehingga dapat meningkatkan kepuasan kerja karyawan dan akan berpengaruh pada pencapaian tujuan perusahaan.

Setiap kegiatan yang dilakukan oleh seseorang didorong oleh suatu kekuasaan dalam diri orang tersebut, kekuatan pendorong inilah yang disebut motivasi. Motivasi kerja karyawan dalam suatu organisasi dapat dianggap sederhana dan dapat pula menjadi masalah yang kompleks, karena pada dasarnya manusia mudah untuk dimotivasi dengan memberikan apa yang menjadi keinginannya. Masalah motivasi kerja dapat menjadi sulit dalam menentukan imbalan dimana apa yang dianggap penting bagi seseorang karena sesuatu yang penting bagi seseorang belum tentu penting bagi orang lain. Bila seseorang termotivasi, ia akan berusaha berbuat sekuat tenaga untuk mewujudkan apa yang diinginkannya. Namun belum tentu upaya yang keras itu akan menghasilkan produktivitas yang diharapkan, apabila tidak disalurkan dalam arah yang dikehendaki organisasi.

Kompetensi bagi beberapa profesi menjadi persyaratan penting dalam menjalankan kerangka dan tujuan organisasi. Masalah kompetensi itu menjadi penting, karena kompetensi menawarkan suatu kerangka kerja organisasi yang efektif dan efisien dalam mendayagunakan sumber-sumber daya yang terbatas. Menurut Moeheriono (2010:3) menjelaskan bahwa kompetensi adalah 
karakteristik yang mendasari seseorang berkaitan dengan efektivitas kinerja individu dalam pekerjaannya atau karakteristik dasar individu yang dimiliki hubungan kausal atau sebagai sebab akibat dengan kriteria yang dijadikan acuan, efektif atau berkinerja prima atau superior ditempat kerja atau pada situasi tertentu.

Peningkatan kompetensi kerja karyawan dalam suatu organisasi yang memadai berperan serta dalam kinerja karyawan yang nantinya dapat meningkatkan kinerja organisasi. Setiap organisasi pasti mempunyai suatu tujuan dan untuk mencapai tujuan tersebut, diperlukan pelaksanaan tugas yang efektif dari para karyawan. Pencapaian tujuan itu sendiri merupakan suatu sasaran yang dikehendaki dan sudah ditetapkan sebelumnya. Kompetensi kerja yang tinggi, seorang karyawan akan mampu berbuat banyak bagi organisasi, sebaliknya dengan kompetensi yang rendah seorang karyawan tidak akan dapat menyelesaikan tugasnya dengan sebaik-baiknya, yang akhirnya akan menghambat pencapaian tujuan organisasi.

Lingkungan kerja adalah lingkungan dimana karyawan melakukan pekerjaannya sehari-hari. Lingkungan kerja yang kondusif memberikan rasa aman dan memungkinkan para karyawan untuk bekerja optimal. Lingkungan kerja dapat mempengaruhi emosi karyawan. Jika karyawan menyenangi lingkungan kerja dimana dia bekerja, maka karyawan tersebut akan betah di tempat kerjanya untuk melakukan aktivitas sehingga waktu kerja dipergunakan secara efektif dan optimis prestasi kerja karyawan juga tinggi. Lingkungan kerja adalah hal-hal yang ada di sekitar pekerja yang dapat mempengaruhi dirinya dalam menjalankan tugas-tugas yang dibebankan. Jadi lingkungan kerja dapat berpengaruh terhadap pekerjaan yang dilakukan. Maka setiap perusahaan atau instansi haruslah mengusahakan agar faktor-faktor yang termasuk dalam lingkungan kerja diusahakan akan sedemikian rupa sehingga mempunyai pengaruh yang baik bagi karyawan untuk semangat kerja. Lingkungan kerja merupakan bagian yang penting dalam perusahaan. Menurut Sedarmayanti (2009:26) lingkungan kerja terbagi menjadi dua yaitu lingkungan kerja fisik dan lingkungan kerja non fisik. Lingkungan kerja fisik diantaranya adalah penerangan, temperatur, kelembaban, sirkulasi udara, 
kebisingan, getaran mekanis, bau tidak sedap, tata warna, dekorasi, musik, dan keamanan di tempat kerja. Sedangkan lingkungan kerja non fisik diantaranya adalah hubungan sosial di tempat kerja baik antara atasan dengan bawahan atau hubungan antara bawahan.

Kepuasan kerja merupakan sikap umum seorang individu terhadap pekerjaannya, seorang dengan tingkat kepuasan kerja tinggi menunjukkan sikap yang positif terhadap pekerjaan itu, seorang yang tidak puas dengan pekerjaannya menunjukkan sikap negatif terhadap pekerjaan itu (Robbins, 2009: 139). Ketika seorang merasakan kepuasan dalam bekerja tentunya ia akan berupaya semaksimal mungkin dengan segenap kemampuan yang dimilikinya untuk menyelesaikan tugas pekerjaannya. Demikian hasil kerja karyawan akan meningkat secara optimal. Mencapai tingkat kepuasan kerja yang maksimal dalam setiap pelaksanaan tugas audit, auditor akan selalu menghadapi faktor-faktor yang diperkirakan dapat mempengaruhi kepuasan kerja. Menurut Handoko (2013:193) menyatakan bahwa kepuasan kerja (job satisfaction) adalah keadaan emosional yang menyenangkan atau tidak menyenangkan dengan mana karyawan memandang pekerjaan mereka.

Kepuasan kerja karyawan merupakan faktor yang dianggap penting, karena dapat mempengaruhi jalannya organisasi secara keseluruhan. Kepuasan yang dirasakan karyawan dalam bekerja merupakan suatu petunjuk bahwa karyawan memiliki perasaan senang dalam menjalankan tugas pekerjaan. Kepuasan kerja juga merupakan suatu sikap positif karyawan terhadap berbagai situasi di tempat pekerjaan. Bagi organisasi, kepuasan kerja karyawan harus mendapat perhatian dan pemenuhan hal ini terutama menjadi tugas pimpinan organisasi. Bagi karyawan, kepuasan kerja merupakan faktor individu dan sarana untuk mencapai produktivitas kerja. Jadi dalam lingkup manajemen sumber daya manusia, faktor kepuasan kerja memberikan manfaat baik bagi organisasi, karyawan, bahkan bagi masyarakat. 
P-ISSN 2580 - 7781

E-ISSN $2615-3238$

\section{METODE PENELITIAN}

Teknik sampling yang digunakan dalam penelitian ini adalah probability sampling dengan pengambilan proportionate stratified random sampling. Menurut Sugiyono (2016:82), probability sampling adalah teknik pengambilan sampel yang memberikan peluang yang sama bagi setiap unsur (anggota) populasi untuk dipilih menjadi anggota sampel. Hal ini setiap anggota populasi memiliki kesempatan yang sama untuk dijadikan sampel. Kriteria yang digunakan peneliti menggunakan teknik proportionate stratified random sampling, ini digunakan bila populasi mempunyai anggota/unsur yang tidak homogen dan berstrata secara proporsional (Sugiyono, 2016:82). Jumlah ditentukan berdasarkan pada perhitungan dari rumus Slovin dengan tingkat kesalahan yang ditoleransi sebesar 10\% (Umar, 2008:146) Berdasarkan hasil rumus Slovin tersebut maka sampel yang diambil dalam penelitian ini adalah 86 orang dengan masing-masing sampel untuk bagain/unit harus proposional sesuai dengan populasi.

Data yang dikumpulkan melalui kuisioner dianalisis dengan analisa regresi linear berganda untuk mengetahui seberapa besar pengaruh variabel bebas yaitu motivasi (X1), kompetensi (X2), dan lingkungan kerja (X3) terhadap variabel terikat yaitu kepuasan kerja (Y) di PT. Indah Plywood Bondowoso. Penelitian ini analisis regresinya menggunakan bantuan program komputer SPSS 22.0 for Windows. Menurut Sanusi, (2011:135) untuk mengetahui pengaruh variabel bebas terhadap variabel terikat digunakan rumus analisis regresi linier berganda sebagai berikut:

$\mathrm{Y}=a+\mathrm{b} 1 \mathrm{X} 1+\mathrm{b} 2 \mathrm{X} 2+\mathrm{b} 3 \mathrm{X} 3+\mathrm{e}$

Keterangan: Y : Kepuasan kerja

X1 : Motivasi kerja

X2 : Kompetensi

X3 : Lingkungan kerja

a : Konstanta

b1 b2 b3 : Koefisien regresi e : Error 
P-ISSN 2580 - 7781

E-ISSN $2615-3238$

\section{HASIL PENELITIAN DAN PEMBAHASAN}

\section{Deskripsi Pengaruh Motivasi Kerja Terhadap Kepuasan Kerja}

Hasil analisis menunjukkan bahwa motivasi kerja berpengaruh positif signifikan terhadap kepuasan kerja karyawan. Berdasarkan pengujian tersebut maka dapat disimpulkan bahwa hipotesis pertama yang menyatakan ada pengaruh secara parsial antara motivasi kerja terhadap kepuasan kerja karyawan pada PT. Indah Plywood Kabupaten Bondowoso adalah diterima. Hasil ini mengindikasikan bahwa jika persepsi karyawan tentang motivasi kerja meningkat maka kepuasan kerja karyawan juga akan meningkat, dan sebaliknya jika persepsi karyawan tentang motivasi kerja meningkat maka kepuasan kerja karyawan juga akan menurun dengan demikian Perlunya alternatif ini, didasarkan pada pertimbangna bahwa, sebuah instansi atau kantor bukan saja mengharapkan para karyawan yang mampu, cakap dan terampil, tetapi yang paling penting mereka mau bekerja giat dan berkeinginan untuk mencapai hasil kerja yang optimal. Oleh karena itu motivasi kerja sangatlah penting untuk mencapai kinerja karyawan, karena dengan adanya motivasi kerja baik dari diri sendiri maupun lingkungan kerja maka karyawan akan merasa bersemangat dalam menjalankan tugasnya. Sejalan dengan pendapat Dian Mardiono (2014) menyatakan bahwa motivasi, kerja berpengaruh signifikan terhadap kepuasan kerja karyawan karyawan.

\section{Deskripsi Pengaruh Kompetensi Terhadap Kepuasan Kerja Karyawan}

Hasil analisis menunjukkan bahwa kompetensi berpengaruh positif signifikan terhadap kepuasan kerja karyawan. Berdasarkan pengujian tersebut maka dapat disimpulkan bahwa hipotesis pertama yang menyatakan ada pengaruh secara parsial antara kompetensi terhadap kepuasan kerja karyawan di PT. Indah Plywood Kabupaten Bondowoso adalah diterima. Hasil ini mengindikasikan bahwa jika persepsi karyawan tentang kompetensi meningkat maka kepuasan kerja karyawan juga akan meningkat, dan sebaliknya jika persepsi karyawan tentang kompetensi menurun maka kepuasan kerja karyawan juga akan menurun. Setiap Pengelolaan hubungan kerja dan pengendalian hubungan kerja dan pengendalian emosional di tempat kerja itu sangat perlu untuk diperhatikan karena akan memberikan dampak terhadap prestasi kerja karyawan. Hal ini disebabkan 
P-ISSN 2580 - 7781

E-ISSN 2615 - 3238

karena manusia itu bekerja bukan sebagai mesin. Manusia mempunyai perasaan untuk dihargai dan bukan bekerja untuk uang saja. Hal ini sejalan dengan Himawan Chandra Hadinata (2014) menunjukkan bahwa variabel lingkungan kerja dan kompensasi berpengaruh positif signifikan terhadap kepuasan kerja karyawan.

\section{Deskripsi Pengaruh Lingkungan Kerja Terhadap Kepuasan Kerja karyawan}

Hasil analisis menunjukkan bahwa lingkungan kerja berpengaruh positif signifikan terhadap kepuasan kerja karyawan. Berdasarkan pengujian tersebut maka dapat disimpulkan bahwa hipotesis pertama yang menyatakan ada pengaruh secara parsial antara lingkungan kerja terhadap kepuasan kerja karyawan PT. Indah Plywood Kabupaten Bondowoso adalah diterima. Hasil ini mengindikasikan bahwa jika persepsi karyawan tentang lingkungan kerja meningkat maka kinerja juga akan meningkat, dan sebaliknya jika persepsi karyawan tentang lingkungan kerja menurun maka kinerja juga akan menurun. Hasil penelitian menunjukkan bahwa responden yaitu karyawan di PT. Indah Plywood Kabupaten Bondowoso menyatakan bahwa keadaan lingkungan kerja yang baik memberikan kenyamanan kepada manusia yang bekerja di dalamnya, sehingga mereka merasa bersemangat, bergairah dan memperoleh kepuasan dalam bekerja.. Persepsi tersebut mampu mempengaruhi kepuasan kerja karyawan sehingga memiliki keinginan untuk slalu bersemangat dalam melakukan pekerjaanya. Sejalan dengan penelitian Hasnur Wansyahdio (2015) bahwa lingkungan kerja berpengaruh signifikan terhadap kepuasan kerja karyawan di Pabrik PT. Eka Dura Indonesia.

\section{Hasil Statistik}

\section{a. Analisa Regresi Linier Berganda}

Berdasarkan persamaan regresi linier berganda yaitu $\mathrm{Y}=-2,578 \mathrm{E}-17+$ $0,199 \mathrm{X} 1+0,337 \mathrm{X} 2+0,344 \mathrm{X} 3+e$ menunjukkan arti dan dapat dijelaskan bahwa nilai konstanta, dengan demikian nilai konstanta ini menunjukan besarnya nilai variabel kepuasan kerja karyawan pada PT. Indah Plywood Bondowoso sebesar 2,578E-17, jika variabel lain (variabel dependen) sama dengan nol atau konstan. 
Besarnya koefisien regresi variabel motivasi kerja (X1) yang berarti setiap peningkatan variabel motivasi kerja sebesar 1\%, maka kepuasan kerja karyawan meningkat 0,199 dengan asumsi variabel lain (kompetensi dan lingkungan kerja) konstan. Besarnya koefisien regresi variabel kompetensi (X2) yang berarti setiap peningkatan variabel kompetensi sebesar 1\%, maka kepuasan kerja karyawan meningkat 0,337 dengan asumsi variabel lain (motivasi kerja dan lingkungan kerja) konstan. Besarnya koefisien regresi variabel lingkungan kerja (X3) yang berarti setiap peningkatan variabel lingkungan kerja sebesar $1 \%$, maka kepuasan kerja karyawan meningkat 0,344 dengan asumsi variabel lain (motivasi kerja dan kompetensi) konstan. Nilai residu/kemungkinan kesalahan dari model persamaan regresi yang disebabkan adanya kemungkinan variabel lainnya yang dapat mempengaruhi variabel kepuasan kerja karyawan (Y) tetapi tidak dimasukkan kedalam model persamaan.

\section{b. Hasil Uji Hipotesis}

1) Hasil Uji t

Pada uji $\mathrm{t}$ menunjukkan bahwa nilai $\mathrm{t}_{\text {hitung }}$ untuk variabel motivasi kerja sebesar 2,076. Sementara itu nilai pada $\mathrm{t}_{\text {tabel }}$ distribusi 5\% sebesar 1,989, maka $\mathrm{t}_{\text {hitung }} 2,076>\mathrm{t}_{\text {tabel }} 1,989$ maka Ha diterima dan Ho ditolak. Hal ini juga diperkuat dengan nilai signifikan $0,041<0,05$ dan nilai $t_{\text {hitung }}$ untuk variabel kompetensi sebesar 3,451. Sementara itu nilai pada $t_{\text {tabel }}$ distribusi $5 \%$ sebesar 1,989, maka $t_{\text {hitung }} 3,451>t_{\text {tabel }}$ 1,989 maka Ha diterima dan Ho ditolak. Hal ini juga diperkuat dengan nilai signifikan $0,001<0,05$ sedangkan nilai $t_{\text {hitung }}$ untuk variabel lingkungan kerja sebesar 3,578. Sementara itu nilai pada $t_{\text {tabel }}$ distribusi $5 \%$ sebesar 1,989, maka $t_{\text {hitung }} 3,578>t_{\text {tabel }}$ 1,989. Ha diterima dan Ho ditolak. Hal ini juga diperkuat dengan nilai signifikan $0,001<0,05$ artinya variabel variabel motivasi kerja, kompetensi dan lingkungan kerja berpengaruh secara parsial terhadap kepuasan kerja karyawan pada PT. Indah Plywood Kabupaten Bondowoso. 
2) Hasil Uji F

Uji $\mathrm{F}$ menunjukkan bahwa nilai $\mathrm{F}_{\text {hitung }} 12,487>\mathrm{F}_{\text {tabel }}$ 2,72 dengan tingkat signifikan yang diperoleh $0,000<0,05$ maka Ha diterima dan Ho ditolak, jadi dapat disimpulkan bahwa variabel motivasi kerja, kompetensi, lingkungan kerja berpengaruh secara simultan terhadap kepuasan kerja karyawan pada PT. Indah Plywood Kabupaten Bondowoso.

3) Hasil Uji Dominan

Berdasarkan uji dominan variabel independen dengan menunjukkan bahwa ada pengaruh positif variabel bebas terhadap variabel terikat, dengan nilai $t_{\text {hitung }}$ variabel motivasi kerja (X1) sebesar 2,076, kompetensi (X2) sebesar 3,451, lingkungan kerja (X3) sebesar 3,578 maka kesimpulannya adalah nilai dari variabel lingkungan kerja tersebut lebih besar dari variabel kompetensi dan motivasi kerja dengan demikian, hipotesis penelitian (H3) yang menyatakan bahwa variabel lingkungan kerja berpengaruh dominan terhadap kepuasan kerja karyawan diterima.

\section{c. Tingkat Koefisien Determinasi}

Nilai koefisien determinasi atau R square menunjukkan nilai sebesar 0,314, dari hasil tersebut berarti seluruh variabel bebas (motivasi kerja, kompetensi, lingkungan kerja) mempunyai kontribusi sebesar 31,4\% terhadap variabel terikat (kepuasan kerja karyawan) dan sisanya sebesar 68,6\% dipengaruhi oleh variabel lain yang tidak masuk dalam penelitian.

\section{KESIMPULAN}

Variabel motivasi (X1), kompetensi (X2) dan lingkungan kerja (X3) memiliki pengaruh yang positif terhadap variabel kinerja karyawan (Y), hal itu ditunjukkan dalam hasil analisis regresi linier berganda yaitu $\mathrm{Y}=-2,578 \mathrm{E}-17+$ $0,199 \mathrm{X} 1+0,337 \mathrm{X} 2+0,344 \mathrm{X} 3+e$. Variabel variabel motivasi kerja, kompetensi dan lingkungan kerja berpengaruh secara parsial terhadap kepuasan kerja karyawan pada PT. Indah Plywood Kabupaten Bondowoso. Variabel motivasi kerja, kompetensi, lingkungan kerja berpengaruh secara simultan terhadap kepuasan kerja karyawan pada PT. Indah Plywood Kabupaten Bondowoso. 
P-ISSN 2580 - 7781

E-ISSN $2615-3238$

Sementara itu Nilai koefisien determinasi atau $\mathrm{R}$ square menunjukkan nilai sebesar 0,314, dari hasil tersebut berarti seluruh variabel bebas (motivasi kerja, kompetensi, lingkungan kerja) mempunyai kontribusi sebesar 31,4\% terhadap variabel terikat (kepuasan kerja karyawan) dan sisanya sebesar 68,6\% dipengaruhi oleh variabel lain yang tidak masuk dalam penelitian.

\section{DAFTAR PUSTAKA}

Arikunto, S. 2013. Prosedur penelitian: Suatu Pendekatan Praktik. (Edisi Revisi). Jakarta: Rineka Cipta.

Bangun, W. 2012. Manajemen Sumber Daya Manusia. Jakarta: Erlangga.

Ghozali, I. 2011. Aplikasi Analisis Multivariate dengan SPSS. Semarang: Badan Penerbit UNDIP.

Gomes, F C, 2018, Manajemen Sumber Daya Manusia. Yogyakarta: Penerbit Andi.

Handoko, T. H. 2013. Manajemen Personalia dan Sumber Daya Manusia. BPFE Yogyakarta.

Hasibuan, M. 2010. Manajemen Dasar, Pengertian, dan Masalah. Jakarta: PT Bumi Aksara.

Hutapea, Pdan Nurianna T, 2018, Kompetensi Plus : Teori, Desain, Kasus dan Penerapan untuk HR dan Organisasi yang Dinamis, Jakarta: Gramedia Pustaka Utama.

Iskandar. 2018. Metodologi Penelitian Pendidikan dan Sosial (Kuantitatif dan Kualitatif). Jakarta: GP Press.

Kadarisman, M. 2012. Manajemen Pengembangan Sumber Daya Manusia, Edisi Pertama, Cetakan pertama, Jakarta: Rajawali Press.

Mangkunegara, AA 2009. Manajemen Sumber Daya Manusia. Bandung: PT. Remaja Rosdakarya.

Martono, N. 2011. Metode Penelitian Kuantitatif. Jakarta: PT Raya Grafindo Persada.

Moeheriono. 2010. Pengukuran Kinerja Berbasis Kompetensi. Surabaya: Ghalia Indonesia

Nitisemito, AS.. 2018. Manajemen Personalia, Edisi kedua.Jakarta: Ghalia Indonesia.

Riduwan dan Kuncoro, Engkos Achmad. 2017. Cara Menggunakan dan Memaknai Path Analysis (Analisis Jalur). Bandung: Alfabeta.

Robbins, SP. 2009. Perilaku Organisasi Edisi ke-12, Jakarta: Salemba Empat. 
Santoso, S. 2009. Mengolah Data Statistik Secara Profesional. Jakarta: PT. Alex Media Komputindo.

Sanusi, A. 2011. Metodologi Penelitian Bisnis. Jakarta: Salemba Empat.

Sedarmayanti. 2009. Sumber Daya Manusia dan Produktivitas Kerja. Bandung: CV Mandar Maju.

Sopiah. 2018. Perilaku Organisasi, Yogyakarta: Andi Offset.

Sugiyono, 2016, Metode Penelitian Kuantitatif, Kualitatif dan R\&D, Bandung: Alfabeta.

Suharyadi, P. 2009. Statistika Untuk Ekonomi dan Keuangan Modern. Penerbit Salemba Empat. Jakarta.

Sunyoto, D. 2015. Manajemen dan Pengembangan Sumber Daya Manusia (Cetakan Pertama). Yogyakarta: CAPS (Center for Academic Publishing Service)

Sutrisno, E. 2011. Manajemen Sumber Daya Manusia. Cetak Ke Enam. Pranada Media Group, Jakarta.

Thamrin dan Francis T, 2018. Manajemen Pemasaran, Cetakan Pertaman, Jakarta: PT. Raja Grafindo Persada.

Tohardi A. 2010. Pemahaman Praktis Manajemen Sumber Daya Manusia, Bandung: Penerbit Mandar Maju.

Umam, K. 2010. Perilaku Organisasi. Bandung: Pustaka Setia.

Undang-Undang Nomor 32 Tahun 2004 tentang Pemerintahan Daerah. Wibowo. 2010. Manajemen Kinerja. Jakarta: Rajawali Press.

Widarjono, A. 2010. Analisis Statistika Multivariat Terapan. Yogyakarta: UPP STIM YKPN.

Winardi, J, 2018. Motivasi dan Pemotivasian dalam Manajemen. Jakarta. Penerbit PT. Rajagrafindo Indonesia.

Yuniarsih dan Suwatno. 2018. Manajemen Sumber Daya Manusia. Bandung: Alfabeta. 